\title{
Author Correction: Profiling immunoglobulin repertoires across multiple human tissues using RNA sequencing
}

Igor Mandric, Jeremy Rotman, Harry Taegyun Yang (D, Nicolas Strauli, Dennis J. Montoya, William Van Der Wey, Jiem R. Ronas, Benjamin Statz, Douglas Yao, Velislava Petrova, Alex Zelikovsky (D), Roberto Spreafico, Sagiv Shifman (1), Noah Zaitlen (10, Maura Rossetti, K. Mark Ansel (D), Eleazar Eskin \& Serghei Mangul(D)

Correction to: Nature Communications https://doi.org/10.1038/s41467-020-16857-7, published online 19 June 2020.

The original version of this article contained an error in the author affiliations.

Serghei Mangul was incorrectly associated with Quantitative and Computational Biology, University of Southern California, Los Angeles, CA 90089, USA.

This has now been corrected in both the PDF and HTML versions of the article.

Published online: 04 September 2020

\begin{abstract}
(c) Open Access This article is licensed under a Creative Commons Attribution 4.0 International License, which permits use, sharing, adaptation, distribution and Ceproduction in any medium or format, as long as you give appropriate credit to the original author(s) and the source, provide a link to the Creative Commons license, and indicate if changes were made. The images or other third party material in this article are included in the article's Creative Commons license, unless indicated otherwise in a credit line to the material. If material is not included in the article's Creative Commons license and your intended use is not permitted by statutory regulation or exceeds the permitted use, you will need to obtain permission directly from the copyright holder. To view a copy of this license, visit http://creativecommons.org/licenses/by/4.0/.
\end{abstract}

(c) The Author(s) 2020 